\title{
Purification and Properties of Sulfite Oxidase
}

\section{from Human Liver}

\author{
Jean L. Johnson and K. V. Rajagopalan \\ From the Department of Biochemistry, Duke University Medical Center, \\ Durham, North Carolina 27710
}

A в S T R A C T Sulfite oxidase has been purified to near homogeneity from human liver. Properties of the molecule have been investigated and compared to those of the rat liver enzyme which has been isolated in a pure form. Both proteins exist as dimeric molecules with one molybdenum and one cytochrome $b_{5}$-type heme per subunit. The human enzyme has a slightly larger subunit molecular weight $(61,100$ vs. 57,200 daltons $)$ and is a more negatively charged molecule. Decreased reactivity of the human enzyme with various electron acceptors suggests the presence of nonfunctional molybdenum centers in a portion of the molecules isolated. Human liver sulfite oxidase cross-reacts strongly with antibody prepared against the rat liver enzyme. Human enzyme activity is precipitated by antibody at concentrations about twofold greater than required for comparable complexation of rat sulfite oxidase.

\section{INTRODUCTION}

Sulfite oxidase is a molybdo-hemoprotein which serves as the terminal enzyme in the pathway of oxidative degradation of sulfur amino acids. The enzyme has been purified and characterized from bovine (1-3) and chicken livers (4) and extensively studied in the rat in terms of molybdenum metabolism in this species (5-8). In this paper we report the isolation and properties of sulfite oxidase from human liver and the relationship of this enzyme to those from other sources. Particular emphasis will be placed on the comparative properties of the human and rat liver enzymes, since this latter source has recently yielded pure, homogeneous sulfite oxidase, not as yet attained from other species. Characterization of the human enzyme was undertaken in response to well-documented reports of a case of sulfite oxidase de-

\footnotetext{
Received for publication 22 August 1975 and in revised form 28 April 1976.
}

ficiency which was encountered several years ago (9$11)$; the study has taken on additional significance as the result of identification of a second instance of the deficiency disease. ${ }^{1}$

\section{METHODS}

Normal human liver obtained at autopsy was used immediately or frozen for not more than 1 wk at $-20^{\circ} \mathrm{C}$ before isolation of the enzyme. Male Charles-River rats weighing 250-300 $\mathrm{g}$ were obtained from the National Institute of Environmental Health Sciences and maintained on standard laboratory chow and tap water. The rats were killed by decapitation and the livers were excised, rinsed with cold $0.25 \mathrm{M}$ sucrose, and used immediately for enzyme purification.

Sodium sulfite was purchased from Baker and Adamson (Allied Chemical, General Chemical Division, Morristown, N. J.). A 0.1-M solution was prepared and stored frozen in 1-ml portions. Horse heart cytochrome $c$, type III, purchased from Sigma Chemical Co. (St. Louis, Mo.), was made up as a $1-\mathrm{mM}$ solution in $0.1 \mathrm{M}$ Tris- $\mathrm{HCl}, \mathrm{pH} 8.5$, and stored at $4^{\circ} \mathrm{C}$. Freezing and foaming were avoided to prevent the formation of inhibitory polymers (12). Sulfite oxidase activity was assayed at room temperature by monitoring the reduction of cytochrome $c$ at $550 \mathrm{~nm}$. Cuvettes contained 10-20 $\mu$ l enzyme, $0.04 \mathrm{mM}$ ferricytochrome $c, 0.4$ $\mathrm{mM}$ sodium sulfite, and $0.1 \mathrm{M}$ Tris buffer, $\mathrm{pH} 8.5$, to a final volume of $2.5 \mathrm{ml}$. The reaction was started by the addition of sulfite to the assay mixture after the base-line rate of cytochrome $c$ reduction was recorded. A slow nonenzymatic rate of reduction of cytochrome $c$ by sulfite was also noted under these conditions and subtracted from the recorded total rate. In assays of crude homogenates, $0.04 \%$ sodium deoxycholate and $0.5 \mathrm{mM}$ sodium cyanide were included in the assay mixture. $1 \mathrm{U}$ of sulfite oxidase activity was defined as the amount of enzyme which produced an absorbance change of $1.0 / \mathrm{min}$ under the above conditions. By this definition, $7.6 \mathrm{U}$ correspond to $1 \mu \mathrm{mol}$ of cytochrome $c$ reduced per minute (13). Conditions for assay of activity with oxygen and ferricyanide as electron acceptors were as described previously (1). Activity measurements and abscrption spectra were recorded on a Cary 14 spectropho-

\footnotetext{
${ }^{2}$ Dr. Vivian Shih, Massachusetts General Hospital, Boston, Mass. Personal communication.
} 
TABLE I

Purification of Sulfite Oxidase from Human and Rat Livers

\begin{tabular}{|c|c|c|c|c|c|c|c|c|c|c|}
\hline \multirow[b]{2}{*}{ Procedure } & \multicolumn{5}{|c|}{ Human liver } & \multicolumn{5}{|c|}{ Rat liver } \\
\hline & Activity & Protein & $\begin{array}{l}\text { Specific } \\
\text { activity }\end{array}$ & Yield & $\begin{array}{l}\text { Purifi- } \\
\text { cation }\end{array}$ & Activity & Protein & $\begin{array}{l}\text { Specific } \\
\text { activity }\end{array}$ & Yield & $\begin{array}{l}\text { Purif- } \\
\text { cation }\end{array}$ \\
\hline & $U$ & $m g$ & $U / m g$ & $\%$ & factor & $U$ & $m g$ & $U / m g$ & $\%$ & factor \\
\hline Homogenate & 4590 & 56,430 & 0.081 & 100 & 1 & 42,900 & 36,530 & 1.174 & 100 & 1 \\
\hline Centrifugation & 4,551 & 28,290 & 0.161 & 99 & 1.98 & 37,760 & 30,680 & 1.231 & 88 & 1.05 \\
\hline Heat step* & 2,401 & 18,620 & 0.129 & 52 & 1.59 & 30,520 & 13,298 & 2.295 & 71 & 1.95 \\
\hline Ammonium sulfate & 4,288 & 7,975 & 0.538 & 93 & 6.64 & 31,102 & 9,657 & 3.221 & 72 & 2.74 \\
\hline Acetone & 3,675 & 887.5 & 4.14 & 80 & 51.1 & 16,974 & 791.3 & 21.45 & 40 & 18.27 \\
\hline DE-52 & 2,044 & 10.64 & 192 & 45 & 2,370 & 6640 & 8.48 & 783 & 15 & 667 \\
\hline G-200 & 429 & 0.82 & 523 & 9 & 6,459 & 2,530 & 1.92 & 1,318 & 6 & 1,113 \\
\hline
\end{tabular}

The human enzyme profile represents $400 \mathrm{~g}$ liver as starting material; the rat enzyme was from $187 \mathrm{~g}$ liver.

* Activity values for the heat step supernatant reflect some inhibition by sulfate ions carried over into the assay cuvette. This effect is more pronounced in the human liver preparation since larger samples were required for assay.

tometer. Protein was determined by the method of Lowry et al. (14) with bovine serum albumin as standard.

For determination of the dry weight of rat liver sulfite oxidase, protein eluted as the peak tube from Sephadex G-200 (Pharmacia Fine Chemicals, Inc., Piscataway, N. J.) was concentrated and dialyzed against $0.01 \mathrm{M}$ potassium phosphate for $6 \mathrm{~h}$ with two changes. Equal portions of the dialyzed solution and the final change of dialyzing buffer were dried to constant weight in individual tared beakers. Protein weight was taken as the weight of the dried dialyzed solution minus the weight of the dried buffer salts. A portion of the dialyzed protein solution was used for assessment of spectral properties and protein content by the Lowry et al. procedure (14).

DE-52 was obtained from Whatman Inc. (Clifton, N. J.), and Sephadex G-200 from Pharmacia Fine Chemicals, Inc. (Piscataway, N. J.). Diaflo PM-30 ultrafilters were purchased from the Amicon Corp. (Lexington, Mass.) and used for concentration of protein solutions in a stirred cell unit.

Polyacrylamide gel electrophoresis was performed according to the method of Davis (15) as detailed by Jovin et al. (16). Gels were stained for protein with amido black. Previously described procedures were used to stain the gels for heme (17) and sulfite oxidase activity (18). Acrylamide gel electrophoresis in the presence of sodium dodecyl sulfate was carried out according to the method of Weber and Osborn (19). Urea at a concentration of $6 \mathrm{M}$ was included in the denaturing solution and in the gels to enhance the sharpness of protein bands (20). The denaturing solution also contained $0.1 \% \beta$-mercaptoethanol. Standards used were as follows: rabbit muscle phosphorylase b (subunit mol wt, 92,500) obtained from Sigma; human transferrin $(77,000)$ from Sigma, bovine serum albumin $(68,000)$ from Sigma; ovalbumin $(43,000)$ from Pentex Biochemical (Kankakee, III.); bovine carbonic anhydrase $(29,000)$ from Worthington Biochemical Corp. (Freehold, N. J.) and horse heart cytochrome $c(12,300)$ from Sigma. Protein bands were stained with coomassie brilliant blue.

Heme iron was assayed by conversion to the pyridine hemochrome as described by Falk (21). A millimolar extinction coefficient of 21.33 for the $\Delta A_{557 n m-541 n m}$ of the reduced minus oxidized difference spectrum was determined for the pyridine hemochrome of a standard solution of sperm whale myoglobin (Schwartz/Mann, Orangeburg, N.Y.) and applied to the hemochrome values obtained for sulfite oxidase. Molybdenum was assayed by a colorimetric procedure described previously (7).

For preparation of antiserum, rabbits were injected with 1-2 mg of purified rat liver sulfite oxidase emulsified with Freund's complete adjuvant (Difco Laboratories, Detroit, Mich.). Antiserum of high titre was maintained by periodic injection with enzyme and incomplete adjuvant. Serum was separated from clotted erythrocytes by centrifugation, and the gamma globulin fraction was partially purified by precipitation with $33 \%$ saturated ammonium sulfate. Agar plates for Ouchterlony double immunodiffusion were purchased from Cyclo Chemicals, Div. Travenol Laboratories, Inc., Los Angeles, Calif.

\section{RESULTS}

Purification of sulfite oxidase from human liver. Human liver sulfite oxidase was purified by a procedure similar to those previously described for bovine (1), avian (4), and rat liver (5) sulfite oxidase. The results of a typical purification are shown in Table I. Results obtained during isolation of sulfite oxidase from rat liver are included in the table for comparative purposes. Although the procedures applied for purification of the enzyme from the two sources were identical, the stability of the human enzyme to the various steps which were employed and its relatively strong affinity for DE-52 cellulose proved to be of extreme value in its purification. Thus, even though the specific activity of sulfite oxidase in the human liver was less than $10 \%$ of that in rat liver, excellent yield and improved purification ratios, especially on the DE-52 column, allowed isolation of the human enzyme in a state of purity not far removed from the entirely homogeneous nature of the rat liver enzyme. Details of the purification procedure are as follows.

Livers were homogenized in a Waring blendor (Waring Products, New Hartford, Conn.) with 6 vol of 0.01 
$\mathrm{M}$ potassium phosphate, $\mathrm{pH}$ 7.8. This and all other buffers used during the isolation procedure contained 0.1 $\mathrm{mM}$ EDTA. The homogenate was centrifuged for 20 $\min$ at $9,000 \mathrm{rpm}$ in a Sorvall refrigerated centrifuge (Sorvall, Ivan, Inc., Norwalk, Conn.) using a GS3 rotor. Solid ammonium sulfate ( $114 \mathrm{~g} /$ liter) was added to the supernate to $20 \%$ saturation. This solution was heated to $58^{\circ} \mathrm{C}$ in a boiling water bath and after $1 \mathrm{~min}$ at this temperature, cooled to $15^{\circ} \mathrm{C}$ in an ice water bath, and centrifuged again for $20 \mathrm{~min}$ at $9,000 \mathrm{rpm}$. The supernatant solution from the heat step was brought to $55 \%$ saturation by the addition of solid ammonium sulfate $(225 \mathrm{~g} /$ /iter $)$. After stirring for $15 \mathrm{~min}$ at $4^{\circ} \mathrm{C}$, the precipitate was collected by centrifugation and resuspended in 5 vol of $0.05 \mathrm{M}$ potassium phosphate. Acetone fractionation was performed as follows: the suspension was placed in an ice bath and 0.75 vol of cold acetone $\left(-20^{\circ} \mathrm{C}\right)$ was added with stirring $(0-43 \%$ fraction $)$. Insoluble material was pelleted by brief centrifugation, and the supernate was treated with additional $0.75 \mathrm{vol}$ of cold acetone (43-60\% fraction). The resulting precipitate containing the sulfite oxidase protein was suspended in $0.01 \mathrm{M}$ potassium phosphate, clarified by centrifugation, and dialyzed for $2 \frac{1}{2}-3 \mathrm{~h}$ at $4^{\circ} \mathrm{C}$ against a large volume of $0.005 \mathrm{M}$ potassium phosphate buffer. When the conductivity of the solution reached that of $0.05 \mathrm{M}$ potassium phosphate, it was applied to a column $(2 \times 15 \mathrm{~cm})$ of DEAE-cellulose equilibrated at $4^{\circ} \mathrm{C}$

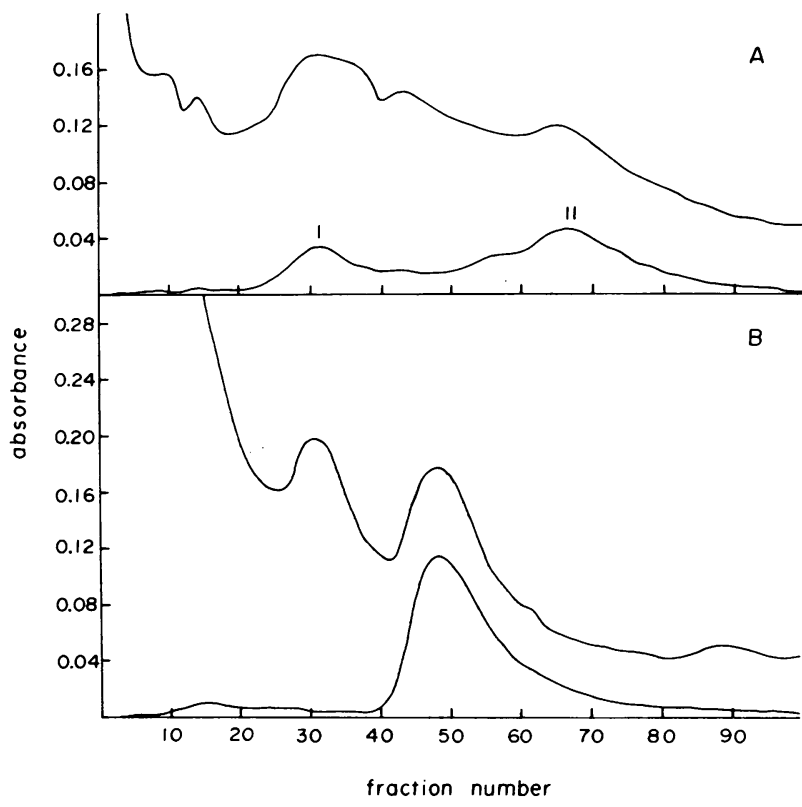

Figure 1 Elution patterns of human (A) and rat liver (B) sulfite oxidase from DEAE-cellulose. Column size and volumes of elution buffers were matched for the two runs. The upper curves in each profile represent absorption at $280 \mathrm{~nm}$; lower curves are absorption values at $413 \mathrm{~nm}$.

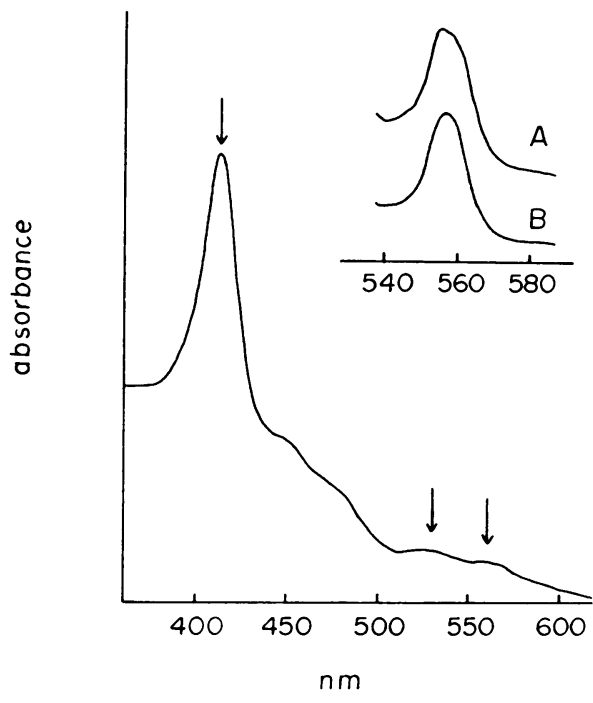

Figure 2 Absorption spectrum of the cytochrome $b_{5}$ present in the human liver preparation, eluting as peak $I$ on DEAE-cellulose. The arrows indicate absorption maxima characteristic of the $b_{5}$ heme, at $413 \mathrm{~nm}$ (Soret), $530 \mathrm{~nm}$ ( $\beta$ band) and $560 \mathrm{~nm}$ ( $\alpha$ band) (22). The inset compares the $\alpha$ band of this cytochrome from peak I (A) and that of native sulfite oxidase (B) which elutes as peak II on DE-52, after reduction by dithionite.

with the same buffer. The column was washed with 0.05 $M$ potassium phosphate until the unadsorbed proteins were eluted. A linear gradient from 0.05 to $0.20 \mathrm{M}$ potassium phosphate was then applied. The elution profiles of human and rat liver sulfite oxidase proteins from the DE-52 column are shown in Fig. 1. All sulfite oxidizing enzymes isolated thus far contain cytochrome $b_{0}$ as a prosthetic group. Thus, the absorption maximum of the cytochrome Soret band at $413 \mathrm{~nm}$ is a convenient monitor of the enzyme and is plotted in Fig. 1. In the case of the rat enzyme, the single $413 \mathrm{~nm}$ peak corresponds exactly to sulfite oxidase activity. The DE-52 profile of the human enzyme shows two $413 \mathrm{~nm}$ absorbance peaks of approximately equal intensity. Sulfite oxidase activity is found almost entirely with peak II at the end of the gradient; only about $1 \%$ of the total activity eluted from the column is found in the early 413 $\mathrm{nm}$ peak. The absorption spectrum of the early peak is that of a $b_{5}$-type cytochrome as shown in Fig. 2, although the presence of flavoproteins in the mixture is also apparent. Electrophoresis of proteins in this peak on polyacrylamide gels revealed a single heme band running with or slightly ahead of the dye front. This behavior was suggestive of the presence of a significant quantity of a low molecular weight $b_{s}$-type cytochrome. As such, it could correspond either to microsomal cytochrome $b_{s}$ or to a mitochondrial small cytochrome $b_{5}$ as described by Fukushima et al. (23) in rat liver and shown to be a proteolytic degradation product of native sulfite oxi- 


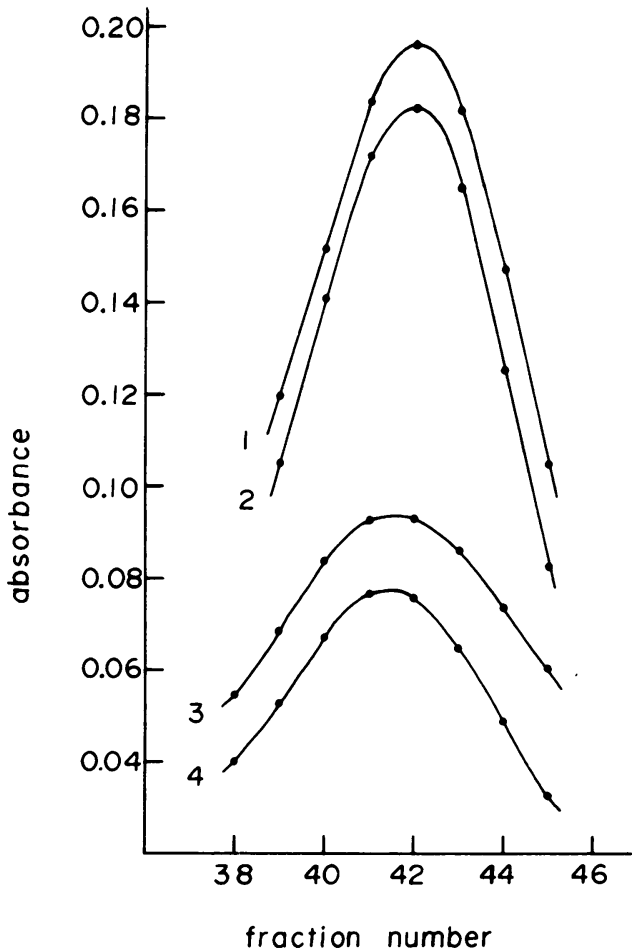

FIGURE 3 Elution patterns of human and rat liver sulfite oxidase from Sephadex G-200. The two samples were run independently on the same Sephadex column. Curves 1 and 2 are 280 and $413 \mathrm{~nm}$ profiles, respectively, for the rat liver enzyme. Curves 3 and 4 are corresponding profiles for the human enzyme.

dase. To distinguish between these two possibilities, the peak I preparation was reduced with dithionite and the $\alpha$-band of the cytochrome spectrum was examined in detail. As seen in the inset to Fig. 2, the reduced spectrum shows an asymmetric $\alpha$ band with a maximum at $556 \mathrm{~nm}$ and a shoulder at about $560 \mathrm{~nm}$. Identical spectral properties have been reported for rat liver microsomal cytochrome $b_{5}$ by Ito (24). In contrast, the rat liver mitochondrial small cytochrome $b_{5}(24)$, native rat liver sulfite oxidase $(7,24)$, and native sulfite oxidase from human liver (Fig. 2) show absorption spectra characterized by a symmetrical $\alpha$ band at $557 \mathrm{~nm}$. Thus we can conclude that the early $413 \mathrm{~nm}$ peak seen on DE-52 chromatography of the human liver preparation is primarily microsomal cytochrome $b_{5}$ and not a proteolytic fragment derived from sulfite oxidase. Proteolytic activity in the liver before autopsy and during enzyme isolation was apparently sufficient to release significant amounts of this protein from its membrane locus such that it was recovered in the hypotonic supernatant fraction. The rat liver preparation, where fresh livers were used immediately for enzyme isolation, showed very little or no release of any low molecular weight $b_{5}$ cytochrome.
A second notable feature of the DE-52 elution profile for human sulfite oxidase is the tightness of the binding of the active enzyme to the column under the ionic conditions applied. Peak activity eluted nearly 20 tubes (200 $\mathrm{ml}$ ) later than the rat liver enzyme. This would suggest that the human enzyme contains a greater proportion of negatively charged residues than does the rat liver protein.

For further purification, fractions of peak activity from DEAE-cellulose were pooled and concentrated to about $1 \mathrm{ml}$ by ultrafiltration. These solutions were then applied to a column $(2.5 \times 90 \mathrm{~cm})$ of Sephadex G-200 which had been equilibrated with $0.05 \mathrm{M}$ potassium phos-

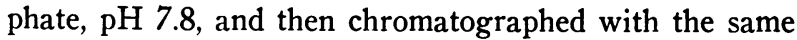
buffer. The elution patterns of human and rat liver sulfite oxidases from Sephadex G-200 are shown in Fig. 3. It can be seen that each enzyme eluted from the column in a symmetrical peak with congruent absorption at 413 and $280 \mathrm{~nm}$. The elution volume for the human enzyme, however, was slightly smaller than that for the rat enzyme, indicative of a slightly larger molecular weight for human sulfite oxidase. The $413 / 280 \mathrm{~nm}$ absorbance ratio of the peak tubes from the rat enzyme profile was 0.94 ; the highest ratio obtained for human sulfite oxidase was 0.83 .

Properties of human liver sulfite oxidase. The results of polyacrylamide gel electrophoresis of human and rat sulfite oxidase preparations are shown in Fig. 4. Both enzymes produced single bands when stained for heme or sulfite oxidase activity. Homogeneity of the rat preparation was evident from the single protein species seen on the acrylamide gel. Minor protein bands seen on the gel of human sulfite oxidase indicated that this preparation was approximately $90 \%$ pure enzyme. The increased mobility of the human enzyme relative to that of the rat enzyme in this gel system is entirely consistent with the behavior on DEAE-cellulose, suggesting that sulfite oxi-

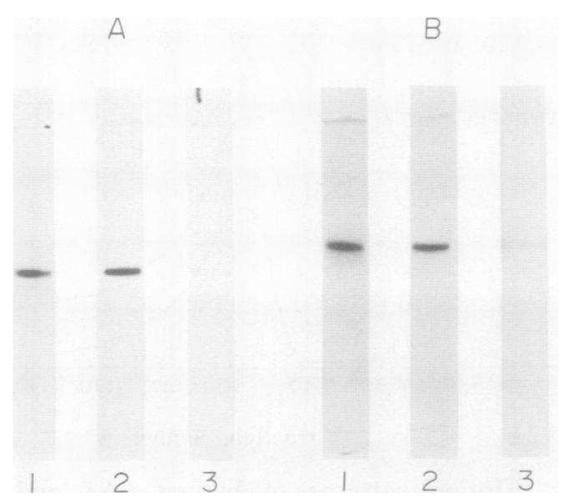

Figure 4 Acrylamide gel electrophoresis of human (A) and rat liver sulfite oxidases (B). Gels contained $7.5 \%$ polyacrylamide and were stained for protein (1), heme (2), or activity (3). 


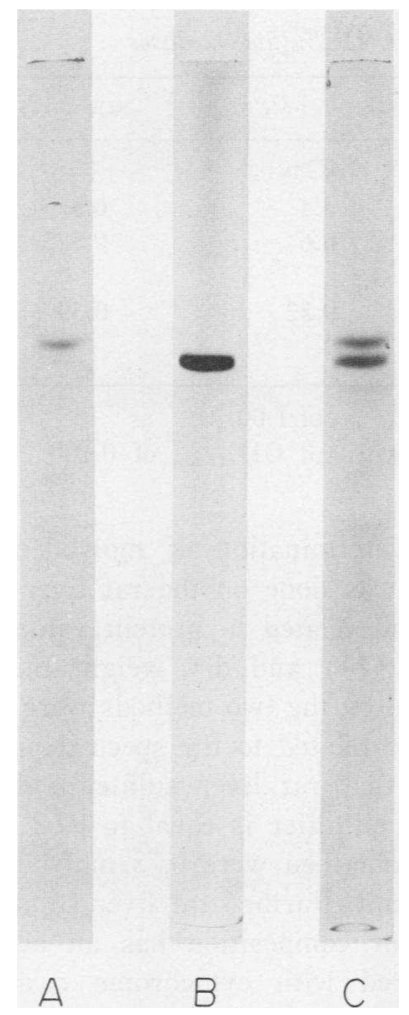

Figure 5 Acrylamide gel electrophoresis of sulfite oxidase from human (A) and rat liver (B) in the presence of sodium dodecyl sulfate. Gel $\mathrm{C}$ contained both human and rat enzymes. Samples from G-200 were concentrated, passed through a G-25 column to remove potassium phosphate, and immediately introduced into the denaturing medium. After several hours of incubation at $37^{\circ} \mathrm{C}$, the samples were applied to the gels and electrophoresed for $18 \mathrm{~h}$ at $5 \mathrm{~mA}$ per tube. Gels contained $7.5 \%$ polyacrylamide.

dase from human liver has a higher proportion of negatively charged residues.

Acrylamide gel electrophoresis in the presence of sodium dodecyl sulfate (Fig. 5) confirmed the purity of the rat liver preparation and again revealed trace contaminants present with the human liver enzyme. Electrophoresis of a mixture of rat and human sulfite oxidases on a single gel resulted in a clear separation of the two proteins. As shown in Fig. 6, the subunit molecular weights of the human and rat enzymes were determined to be 61,100 and 57,200 , respectively. The somewhat larger molecular weight of the human enzyme is consistent with its behavior on Sephadex G-200 and indicates that its greater mobility on acrylamide gels run in the absence of sodium dodecyl sulfate is entirely due to an altered charge distribution. The excess negative charges are in fact sufficient to overcome the retarding effect of larger molecular weight and result in increased mobility relative to the rat liver protein.

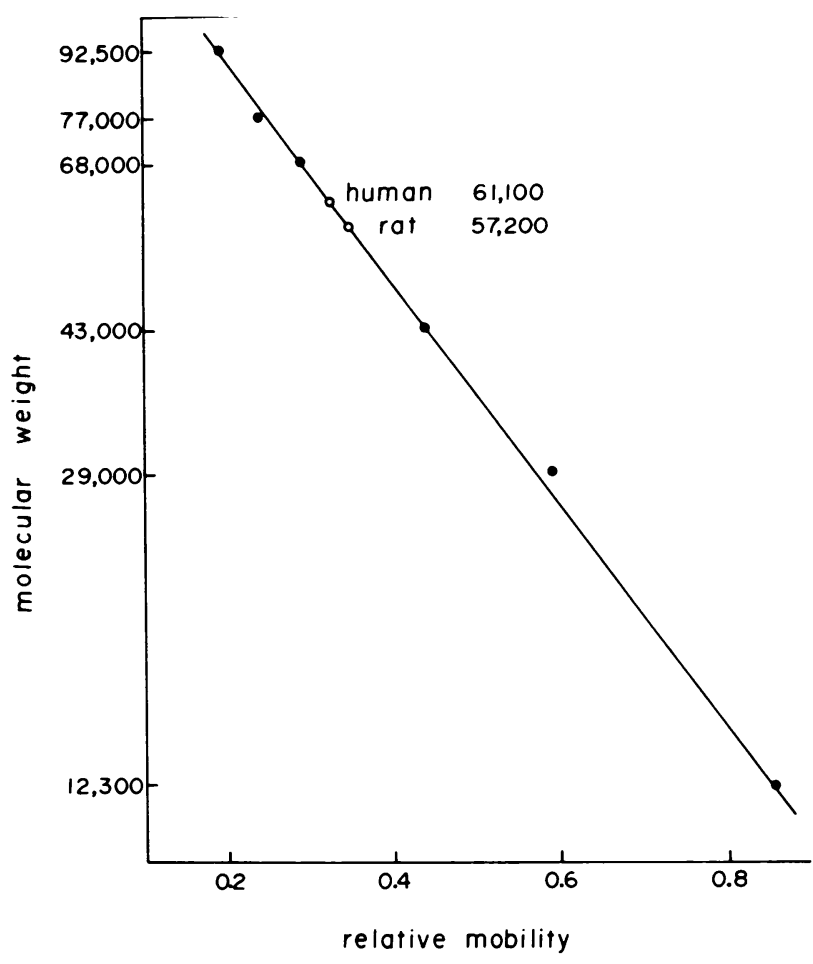

Figure 6 Acrylamide gel electrophoresis of human and rat liver sulfite oxidases in the presence of sodium dodecyl sulfate. Enzymes prepared as in Fig. 5 were applied to $7.5 \%$ polyacrylamide gels along with a mixture of denatured standard proteins. Conditions for electrophoresis were as in Fig. 5.

The subunit molecular weights of sulfite oxidases from chicken (4) and bovine livers (2), at 55,000-56,000 daltons, are somewhat smaller even than that of the rat enzyme. Sedimentation studies on the bovine (2) and chicken enzymes (4) have shown that both proteins are

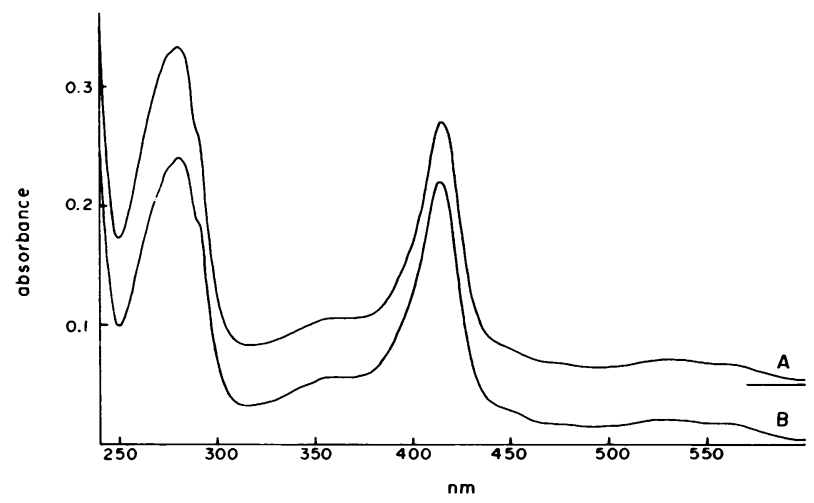

Figure 7 Absorption spectra of sulfite oxidase from human (A) and rat liver (B). Protein solutions were matched in concentration at $413 \mathrm{~nm}$ by dilution in 0.05 potassium phosphate, $\mathrm{pH}$ 7.8. The spectrum of the human enzyme is offset from that of the rat by 0.05 absorbance $U$. 
TABLE II

Molybdenum Contents and Activities of Human and Rat Liver Sulfite Oxidases

\begin{tabular}{|c|c|c|c|c|}
\hline & Molybdenum* & $\mathrm{SO}_{3}-\rightarrow \mathrm{cyt} c t$ & $\mathrm{SO}_{3}-\rightarrow \mathrm{Fe}(\mathrm{CN})_{6 \downarrow}$ & $\mathrm{SO}_{3}-\rightarrow \mathrm{O}_{2} \ddagger$ \\
\hline & $\mu g / m l$ & $U / m l$ & $U / m l$ & $U / m l$ \\
\hline Human & 0.705 & 37.6 & 3.4 & 0.325 \\
\hline Rat & 0.770 & 82.2 & 6.6 & 0.825 \\
\hline Ratio: $\frac{\text { Human }}{\text { Rat }}$ & 0.92 & 0.46 & 0.52 & 0.39 \\
\hline
\end{tabular}

* Molybdenum values are expressed for solutions with an $\mathrm{OD}_{413 \mathrm{~nm}}$ of 1.00 .

† Enzyme activity measurements were made on solutions with an $O D_{113 \mathrm{~nm}}$ of 0.100 .

Assay conditions are described in Methods.

dimeric molecules. Similar elution of enzyme from all four animal sources from Sephadex G-200 allows the conclusion that human and rat liver sulfite oxidases are each composed of two identical subunits, and thus have native molecular weights of about 122,000 and 114,400 , respectively.

Absorption spectra of human and rat liver sulfite oxidases are shown in Fig. 7. The two preparations display remarkably similar spectral properties, particularly in features characteristic of the $b_{5}$ prosthetic group. The somewhat higher absorption at $280 \mathrm{~nm}$ of the human enzyme probably reflects the slight contamination in this preparation; however, the $413 / 280$ ratio of 0.94 obtained with the rat enzyme is certainly not a criterion of purity for judging the human preparation. Additional aromatic residues could well contribute to the increased molecular weight of the human sulfite oxidase molecule and thus define a somewhat lower ratio for the pure enzyme.

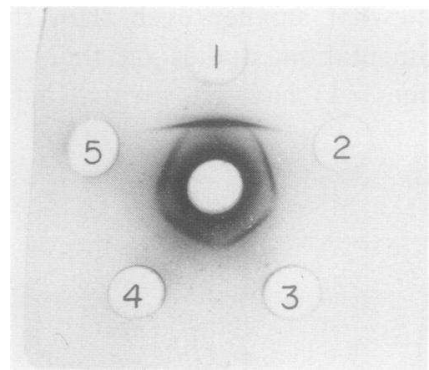

FIGURE 8 Ouchterlony double immunodiffusion of human and rat liver sulfite oxidase preparations. Well 1 contained partially purified rat liver sulfite oxidase (through DEAEcellulose stage) at a concentration of about $300 \mathrm{U} / \mathrm{ml}$. Human liver sulfite oxidase at the same stage of purification was present in wells 2 and 3 at a concentration of $650 \mathrm{U} / \mathrm{ml}$ and in wells 4 and 5 at $1,300 \mathrm{U} / \mathrm{ml}$. The center well contained rabbit antibody prepared against purified rat liver sulfite oxidase at a titre of approximately $1,000 \mathrm{U} / \mathrm{ml}$. Diffusion was allowed to proceed for $24 \mathrm{~h}$ in a humid atmosphere at room temperature. After formation of precipitin bands the plates were soaked in $0.9 \% \mathrm{NaCl}$ to remove uncomplexed proteins, washed in distilled water, dried, and stained with amido black.
A careful determination of molybdenum and heme stoichiometry was done on the rat liver sulfite oxidase preparation and related to protein values measured by Lowry et al. (14) and dry weight methods. Protein values obtained by the two methods were in good agreement and were related to the spectral properties of the enzyme such that rat liver sulfite oxidase protein in milligram per milliliter is equal to $0.62 \times \mathrm{A}_{413} \mathrm{~nm}$. Cofactor values obtained were 0.75 molybdenum and 0.85 heme per subunit. Purified rat liver sulfite oxidase with such a cofactor composition has an activity of 1,320 $\mathrm{U} / \mathrm{mg}$ measured with cytochrome $c$ as the electron acceptor.

Due to the trace contaminants present in the human liver preparation, Lowry protein or dry weight measurements were not accurate indicators of sulfite oxidase protein. Thus, it became more meaningful to relate molybdenum and activity values to spectral properties of the $b_{5}$ heme, which have been rigorously conserved in all of the diverse sources so far examined. Molybdenum to heme and activity to heme ratios are shown in Table II. It can be seen that although the molybdenum content is comparable in the two preparations, the activity of the human enzyme is considerably less than that of the rat enzyme. This observation was seen to apply not only to cytochrome $c$ reduction but to sulfite oxidation with ferricyanide or oxygen as electron acceptors as well.

The great degree of similarity noted between the human and rat sulfite oxidases raised the possibility that the human enzyme might be capable of cross-reacting with an antibody preparation directed against the rat liver enzyme. The Ouchterlony double immunodiffusion plate shown in Fig. 8 provides evidence of considerable cross-reactivity between the two proteins. A strong precipitin band was observed between wells containing human sulfite oxidase and rabbit antirat sulfite oxidase antibody. The spur pattern shows that human and rat enzymes are immunologically related, but not identical, and that the human enzyme possesses some but not all of the determinants recognized on the rat enzyme. 
Fig. 9 compares quantitative reactivities of human and rat liver sulfite oxidases with the antibody directed against the rat enzyme. As can be seen, $50 \%$, of the activity of the human enzyme was precipitated by serum at about $2 \times$ the concentration required to yield similar results with the rat enzyme. This observation attests to the similarity of the two proteins; the slight difference in titer is of course consistent with somewhat fewer recognized determinants on the human sulfite oxidase protein.

\section{DISCUSSION}

Sulfite oxidase has been detected in human autopsy livers at a fairly constant level of 10-25 U/g wet weight of the tissue. This is considerably lower than the level found in an adult rat, $200-250 \mathrm{U} / \mathrm{g}$, or chicken, $100-150 \mathrm{U} / \mathrm{g}$ (4). Bovine liver contains about $50 \mathrm{U} / \mathrm{g}$ (1). The lower specific activity of the human liver enzyme could have posed serious problems in its isolation; however, rather fortuitous behavior at several stages in the purification procedure allowed isolation in good yield and high purity. Two important features in the purification of both rat and human sulfite oxidases not emphasized in the Results should be mentioned. The use of fresh rat livers has been found to be essential for isolation of sulfite oxidase of highest purity. While enzyme activity is undiminished in livers frozen for several months, the properties of the protein are apparently altered such that considerable loss of activity and sulfite oxidase protein are noted at the heat step. Rat or human liver frozen for short periods of time (less than $1 \mathrm{wk}$ ), however, will serve as good starting materials for sulfite oxidase purification. A second consideration in preparation of pure sulfite oxidase is speed in isolation. Enzyme prepared by homogenizing livers in the morning should be chromatographed on DE-52 overnight and after spectral analysis, immediately concentrated and applied to Sephadex G-200. Adherence to this protocol results in the isolation of enzyme of reproducible purity.

Many of the properties of human liver sulfite oxidase have been shown to be identical to those of rat, chicken, and bovine enzymes. The subunit structure and cofactor composition are unaltered in the enzyme from these various sources. The $b_{b}$ cytochrome is identical in all details, including the symmetrical $\alpha$ peak observed in the spectrum of the reduced chromophore.

Two obvious differences between the rat and human proteins were revealed by gel chromatography techniques. The increased negative charge and slightly larger subunit molecular weight of the human enzyme may reflect evolutionary alterations in the protein structure with no apparent effect on catalytic functionality. A study of the distribution and localization of the additional residues and negative charges, however, would

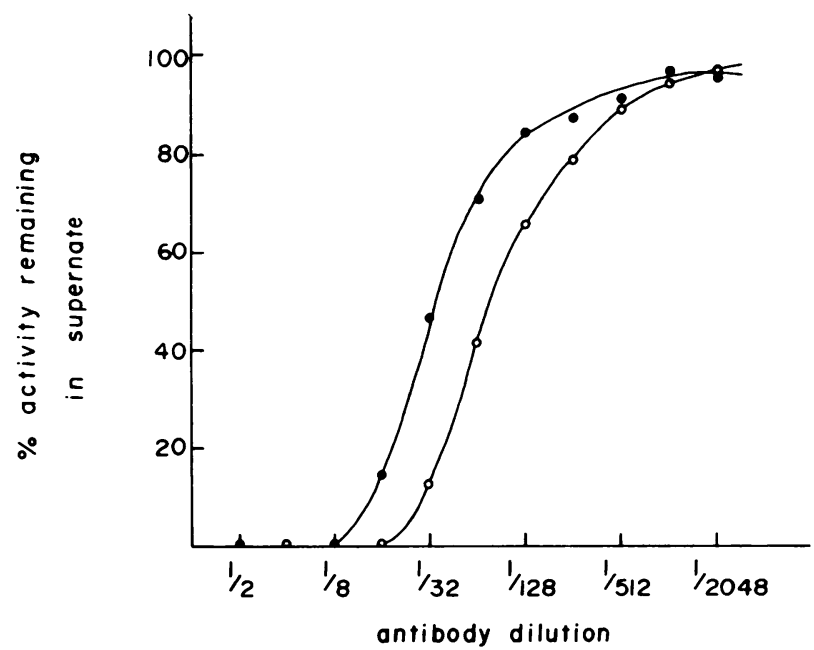

FigURE 9 Precipitation of sulfite oxidase from human ( $\bullet$ and rat liver $(O)$ with rabbit antibody directed against rat liver sulfite oxidase. Human and rat liver enzymes were diluted in $0.01 \mathrm{M}$ potassium phosphate, $\mathrm{pH} 7.8$ with $1 \mathrm{mg} /$ $\mathrm{ml}$ bovine serum albumin to an equal heme concentration with absorbance at $413 \mathrm{~nm}$ of 0.055 . The enzymes were mixed with equal volumes of serial dilutions of antibody in $0.01 \mathrm{M}$ potassium phosphate, and incubated at $0^{\circ} \mathrm{C}$ for $40 \mathrm{~min}$. After centrifugation at $10,000 \mathrm{~g}$ for $10 \mathrm{~min}$, activities remaining in the supernate were assayed. Bovine serum albumin was included in the incubations to insure stability of the enzymes in dilute solution. Conditions employed for antibody complex formation were determined to be optimal for both human and rat enzymes.

be extremely interesting and indeed might reveal an influence on the activity of the enzyme.

The molybdenum center of sulfite oxidase is the vital catalytic center where electrons from sulfite enter the enzyme. The molybdenum centers in the rat (5) and chicken enzymes $(4,25)$ have been investigated extensively by electron paramagnetic resonance spectroscopy and shown to be uniquely sensitive to alterations in $\mathrm{pH}$ and ionic composition of the medium. Similar studies on a crude preparation of human liver sulfite oxidase have been reported previously (4) and have shown that the $\mathrm{pH}$ sensitivity of the molybdenum center is clearly conserved in the human enzyme. Thus, application of electron paramagnetic resonance as a sensitive probe of the geometry of paramagnetic molybdenum in sulfite oxidase detected no difference among the enzymes from various species. Identity of the molybdenum centers by this criterion and the near stoichiometric molybdenum contents of both the rat and human enzymes make the lowered activities observed in the human sulfite oxidase preparation especially intriguing. Lower reactivity in the cytochrome $c$ assay immediately suggested a more stringent requirement for intraspecies cytochrome $c$ in the case of the human enzyme. In fact, additional negative charges near the $b_{5}$ heme of the enzyme could disrupt heme-heme interaction required for transfer of 
electrons to cytochrome $c$ unless the cytochrome $c$ were specifically evolved to recognize the altered surface configuration. However, the lowered reactivities with ferricyanide and oxygen as electron acceptors, which are believed to react with sites on the enzyme other than the heme, make such a postulate unlikely. A more acceptable hypothesis at this point is that in a portion of the human sulfite oxidase molecules as isolated, the molybdenum center is nonfunctional. A careful quantitation of sulfitereducible molybdenum using electron paramagnetic resonance would help to establish whether this is the case.

The cross-reactivity of human sulfite oxidase with the antibody directed against rat enzyme is a particularly important finding. Inhibition of the human enzyme with the available antirat sulfite oxidase antibody preparation provides a convenient and sensitive assay for crossreacting material in tissue samples from sulfite oxidase deficient individuals. The following article (26) describes experiments which investigate in detail the lesion expressed as sulfite oxidase deficiency in one patient. Characterization of human liver sulfite oxidase as reported above is essential groundwork for study of the deficiency disease and has contributed to a better understanding of molybdoenzymes in animal systems.

\section{ACKNOWLEDGMENTS}

This work was supported by Research grant GM 00091 from the National Institutes of Health (to Dr. Rajagopalan) and by National Institutes of Health Postdoctoral Fellowship ES 00036 (to Dr. Johnson).

\section{REFERENCES}

1. Cohen, H. J., and I. Fridovich. 1971. Hepatic sulfite oxidase. Purification and properties. J. Biol. Chem. 246: 359-366.

2. Cohen, H. J., and I. Fridovich. 1971. Hepatic sulfite oxidase. The nature and function of the heme prosthetic groups. J. Biol. Chem. 246: 367-373.

3. Cohen, H. J., I. Fridovich, and K. V. Rajagopalan. 1971. Hepatic sulfite oxidase. A functional role for molybdenum. J. Biol. Chem. 246: 374-382.

4. Kessler, D. L., and K. V. Rajagopalan. 1972. Purification and properties of sulfite oxidase from chicken liver. Presence of molybdenum in sulfite oxidase from diverse sources. J. Biol. Chem. 247: 6566-6573.

5. Kessler, D. L., J. L. Johnson, H. J. Cohen, and K. V. Rajagopalan. 1974. Visualization of hepatic sulfite oxidase in crude tissue preparations by electron paramagnetic resonance spectroscopy. Biochim. Biophys. Acta. 334 : 86-96.

6. Johnson, J. L., K. V. Rajagopalan, and H. J. Cohen. 1974. Molecular basis of the biological function of molybdenum. Effect of tungsten on xanthine oxidase and sulfite oxidase in the rat. J. Biol. Chem. 249: 859866.

7. Johnson, J. L., H. J. Cohen, and K. V. Rajagopalan. 1974. Molecular basis of the biological function of molybdenum. Molybdenum-free sulfite oxidase from livers of tungsten-treated rats. J. Biol. Chem. 249: 5046-5055.
8. Cohen, H. J., J. L. Johnson, and K. V. Rajagopalan. 1974. Molecular basis of the biological function of molybdenum. Developmental patterns of sulfite oxidase and xanthine oxidase in the rat. Arch. Biochem. Biophy's. $164: 440-446$.

9. Irreverre, F., S. H. Mudd, W. D. Heizer, and L. Laster. 1967. Sulfite oxidase deficiency: studies of a patient with mental retardation, dislocated ocular lenses, and abnormal urinary excretion of S-sulfo-L-cysteine, sulfite, and thiosulfate. Biochem. Med. 1: 187-217.

10. Mudd, S. H., F. Irreverre, and L. Laster. 1967. Sulfite oxidase deficiency in man: demonstration of the enzymatic defect. Science (Wash. D. C.). 156: 15991602.

11. Percy, A. K., S. H. Mudd, F. Irreverre, and L. Laster. 1968. Sulfite oxidase deficiency: sulfate esters in tissues and urine. Biochem. Med. 2 : 198-208.

12. Howell, L. G., and I. Fridovich. 1968. Sulfite: cytochrome $c$ oxidoreductase. Inhibition by polymers of cytochrome c. J. Biol. Chem. 243: 5941-5947.

13. Margoliash, E., and A. Schejter. 1966. Cytochrome c. Adv. Protein Chem. 21 : 113-286.

14. Lowry, O. H., N. J. Rosebrough, A. L. Farr, and R. J. Randall. 1951. Protein measurement with the Folin phenol reagent $J$. Biol. Chem. 19: 265-275.

15. Davis, B. J. 1964. Disc electrophoresis-II. Method and application to human serum proteins. Ann. N. Y. Acad. Sci. 121 : 404-427.

16. Jovin, T., A. Chambach, and M. A. Naughton. 1964. An apparatus for preparative temperature-regulated polyacrylamide gel electrophoresis. Anal. Biochem. 9: 351-369.

17. Haut, A., G. R. Tudhope, G. E. Cartwright, and M. M. Wintrobe. 1962. The nonhemoglobin erythrocytic proteins, studied by electrophoresis on starch gel. J. Clin. Invest. $41: 579-587$.

18. Cohen, H. J. 1973. The use of diaminobenzidine for spectrophotometric and acrylamide gel detection of sulfite oxidase and its applicability to hydrogen peroxidegenerating enzymes. Anal. Biochem. 53: 208-222.

19. Weber, K., and M. Osborn. 1969. The reliability of molecular weight determinations by dodecyl sulfate-polyacrylamide gel electrophoresis. J. Biol. Chem. 244: 4406-4412.

20. Schwartz, M. L. 1972. I. Human blood clotting factor XIII (the fibrin stabilizing factor) from plasma and platelets. II. The crosslinking of vertebrate fibrin. Ph.D. Dissertation. Duke University.

21. Falk, J. E. 1964. Porphyrins and metalloporphyrins. Elsevier Publishing Co., Amsterdam. 181.

22. Ikeda. M., T. Iizuka, H. Takao, and B. Hagihara. 1974. Studies on the heme environment of oxidized cytochrome $b_{5}$. Biochim. Biophys. Acta. 336: 15-24.

23. Fukushima, K., A. Ito, T. Omura, and R. Sato. 1972. Occurrence of different types of cytochrome $b_{5}$-like hemoprotein in liver mitochondria and their intramitochondrial localization. J. Biochem. 71: 447-461.

24. Ito, A. 1971. Hepatic sulfite oxidase identified as cytochrome $b_{5}$-like pigment extractable from mitochondria by hypotonic treatment. J. Biochem. 70: 1061-1064.

25. Kessler, D. L., and K. V. Rajagopalan. 1974. Hepatic sulfite oxidase. Effect of anions on interaction with cytochrome c. Biochim. Biophys. Acta. 370: 389-398.

26. Johnson, J. L., and K. V. Rajagopalan. 1976. Human sulfite oxidase deficiency: characterization of the molecular defect in a multicomponent system. J. Clin. Invest. 58: 551-556. 